\title{
Trans,trans-muconic acid in urine samples collected in three periods from benzene handling workers in a Brazilian refinery
}

\author{
${\text { Isarita Martins }{ }^{1 *} \text {, Maria Elisa Pereira Bastos de Siqueira² }}^{2}$ \\ ${ }^{1 *}$ Faculty of Pharmaceutical Sciences, University of São Paulo, ${ }^{2}$ Federal University Centre of Alfenas
}

*Correspondence:

I. Martins

Faculty of Pharmaceutical Sciences

University of San Paulo

Rua Lineu Prestes, 580, Bloco 13B

05508-900 - São Paulo - SP - Brazil

E-mail isarita@usp.br
Trans,trans-Muconic Acid (ttMA), a benzene metabolite, has been recommended as a sensitive bioindicator in the biological monitoring of workers exposed to benzene. In the present study we aimed to evaluate the best urine collecting time for ttMA analysis. This bioindicator was determined in workers who handle benzene once a week and the samples were collected in three periods: preshift (individual background levels), post-shift and in the day after, in the morning. ttMA was analysed by a high pressure liquid chromatography (HPLC) in a reverse-phase column LiChrosorb $R P 18$ and UV detection, after extraction in Dowex $1{ }^{\circledR}$ resin (strongly basic anion). In occupationally exposed workers, ttMA values were significantly higher in post-shift samples $(p=0.025)$ than in the preshift samples or those collected the following day. The results show that the end of the shift is the best period to take urine samples in benzene biomonitoring when analysing ttMA. Tobacco use and ingestion of foods containing sorbic acid did not show significant influence on urinary ttMA levels, but alcohol intake diminished significantly the excretion of this bioindicator in post-shift samples.
Uniterms

- Trans,trans-muconic acid

- Benzene

- Biomonitoring

\section{INTRODUCTION}

Benzene was classified as a group I carcinogen by the International Agency for Research on Cancer (IARC, 1982). It is an important component in petrol and is widely used in chemical, painting and dye industries. In view of its carcinogenic risk, national and international discussions are ongoing in an effort to decrease occupational exposure levels (Ong et al., 1996). Lowering of the acceptable standards induces a need for more sensitive biomarkers.

Biomonitoring of workers exposed to benzene is an important measure for the prevention of occupational intoxication. The biomarkers most used are benzene in exhaled air, in blood, in urine and biotransformation products, trans, trans-muconic acid (ttMA) and $S$ phenylmercapturic acid in urine (S-PMA) (Bechtold, Henderson, 1993; Ong, Lee, 1994).

Many authors have reported ttMA to be a biomarker which allows the detection of low exposure to benzene (Bechtold et al., 1991; Bechtold, Henderson, 1993; Ghittori et al., 1995; Vivoli et al., 1995; Ghittori et al., 1996).

Trans,trans-muconic acid is a product of a highly reactive intermediate, trans, trans-muconaldehyde (Kirley et al., 1989), to which has been attributed the myelotoxic 
and leukaemogenic effects of benzene. Thus, measurement of ttMA allows risk evaluation of benzene exposure, despite its nonspecificity (Scherer et al., 1998; Ducos et al., 1990). Studies performed on workers exposed to benzene showed that there is a close correlation between urinary ttMA concentrations and air benzene levels above 0.5 ppm (Lee et al., 1993).

American Conference of Governmental Industrial Hygienists (ACGIH) reported urinary ttMA as a bioindicator of benzene exposure, with a Biological Exposure Index (BEI) of $0.5 \mathrm{mg} / \mathrm{g}$ creatinine (ACGIH, 2002). Since 1998, ACGIH recommends S -PMA, a minor metabolite of benzene, as exposure biomarker with a BEI of $25 \mathrm{mg} / \mathrm{g}$ creatinine (ACGIH, 1998). This substance is more sensitive and specific than ttMA in the estimation of benzene exposure. However, for its measurement gaschromatography/mass spectrometry is required for adequate sensitivity what put some difficulties for routine monitoring, especially in countries in development, like Brazil.

Taking into account the maximum level of benzene in air permitted by Brazil legislation, as technological reference value (TRV) of $1 \mathrm{ppm}$ in petroleum plants (Brasil, 2001), the use of ttMA as an internal dose biomarker is being considered by Governmental authorities as the most reliable biological indicator for routine purposes. Then, we designed this study to evaluate the best time to collect urine samples to monitoring workers exposed to benzene through urinary ttMA determination, as a part of studies necessary to validate the indicator before it can be widely used. The influence of alcohol, smoking and ingestion of food containing sorbic acid on ttMA excretion was also evaluated.

\section{MATERIAL AND METHODS}

Subjects. The study was conducted in a large petroleum refinery in Cubatão, São Paulo state, Brazil. In this plant, petroleum is converted into other products by many operations. The workers were all involved in many activities with benzene, such as its separation, handling, transportation and in the laboratory of quality control. All workers who handle benzene were volunteers of the study $(\mathrm{n}=25)$. These workers handle benzene only once a week in a 6-h shift. All of them used complete individual protection apparatus: gloves, masks, clothes, during the workshift. They filled out a questionnaire about their home, personal (especially tobacco and alcohol use) and dietary habits, as well as information about their activities in the plant, medicines intake and diseases. Some information were resumed in the Table I. The urine samples were collected into polyethylene bottles and were transported to the laboratory in an ice cooler and frozen at $-20{ }^{\circ} \mathrm{C}$ until analysis, after addition of $\mathrm{HCl} 6 \mathrm{~mol} / \mathrm{L}(1 \mathrm{~mL}$ per $100 \mathrm{~mL}$ urine). Before freezing urine, creatinine was measured using a spectrophotometric standardized method based on Jaffé reaction, and the density was determined with an Urodensimeter ${ }^{\circledR}$. Spot urine was collected in three periods: in pre-shift (individual background levels), post-shift and in the day after, prior the next shift (75 samples).

TABLE I - Some informations, obtained from a questionnaire, about workers who handle benzene in a large petroleum refinery $(n=25)$

\begin{tabular}{ll}
\hline Age (years) & $36(26-45)$ \\
Humangender & 4 women 21 men \\
Cigarette smorkers & 6 \\
Number of cigarettes smoked & $5-8 /$ day \\
Drinkers & 11 \\
$\begin{array}{ll}\text { Interval between the alcohol } \\
\quad \text { ingestion and the sampling }\end{array}$ & $6-30$ hours \\
\hline
\end{tabular}

Chemicals: $98 \%$ ttMA and $97 \%$ vanillic acid (internal standard), Dowex 1 resin 1x2-100 ion-exchangecloride, strongly basic anion (50-100 mesh) and tris(hidroximetil)aminometane were purchased from Aldrich ${ }^{\circledR}$. Sodium acetate, sodium chloride, acetic and chloridric acid were obtained from Merck ${ }^{\circledR}$, methanol (HPLC-grade) was obtained from EM Science ${ }^{\circledR}$.

\section{Mesurement of trans,trans-muconic acid}

Clean-up procedure. The SPE cartridge, filled with $300 \mathrm{mg}$ of Dowex ${ }^{\circledR}$ resin, was previously conditioned and rinsed twice with $2 \mathrm{~mL}$ MilliQ water, $1 \mathrm{~mL} 0.2 \mathrm{mmol} / \mathrm{L}$ phosphoric acid, $1 \mathrm{~mL} 0.1 \mathrm{~mol} / \mathrm{L}$ sodium acetate buffer and finally $1 \mathrm{ml}$ MilliQ water. One $\mathrm{m} l$ of the urine was mixed with $2 \mathrm{ml} 0.5 \mathrm{~mol} / \mathrm{L}$ Tris buffer $\mathrm{pH} 10$ containing $10 \mathrm{mg} / \mathrm{L}$ vanillic acid (internal standard), and passed through the cartridge. ttMA was eluted with $2 \mathrm{~mL} 1.5 \mathrm{~mol} / \mathrm{L}$ sodium chloride/methanol $(1: 1)$.

Chromatographic condition: Analysis was carried out by HPLC, Hewlett Packard ${ }^{\circledR}$, model 1100 (20 mL per injection) with a column $(150 \times 30 \mathrm{~mm})$ filed with LiChrosorb RP18, $5 \mathrm{~mm}$, Chrompack ${ }^{\circledR}$ and a pre-column Chrompack $^{\circledR} \mathrm{R} 2(10 \times 2 \mathrm{~mm})$. The detector was set at 259 $\mathrm{nm} ; 1 \%$ glacial acetic acid/methanol (9:1) was used as mobile phase, with a flow rate of $1 \mathrm{~mL} / \mathrm{min}$. Identification was performed by internal standardization using the 
ChemStation HP. The retention time relative to vanillic acid (ttMA/vanillic acid) was $0.39 \pm 0.02$ and an analytic run taked 15 minutes.

Quantification: The concentration of ttMA in the samples was calculated from a calibration curve prepared in urine spiked with ttMA levels between 0.2 and $5.0 \mathrm{mg}$ ttMA/L and analyzed concomitantly with each set of workers samples. ttMA was expressed in $\mathrm{mg} / \mathrm{L}$ (after correction for urinary density) and in $\mathrm{mg} / \mathrm{g}$ creatinine. Parameters of the method validation were: linearity between 0.2 to $5.0 \mathrm{mg} / \mathrm{L}\left(\mathrm{y}=0.0707 \mathrm{x}+0.869 ; \mathrm{r}^{2}=0.9943\right)$; detection (LOD) and quantification (LOQ) limits were respectively 0.1 and $0.2 \mathrm{mg} / \mathrm{g}$ creatinine); the mean coefficient of variation of replicate analysis $(n=10)$ of 0.2 , 2.0 and $5.0 \mathrm{mg} / \mathrm{L} \mathrm{ttMA} \mathrm{in} \mathrm{spiked} \mathrm{samples} \mathrm{were} 7.7 \%$ (repetibility) and 10.6\% (day-by-day precision); the mean recovery of ttMA was $87.1 \%$ for the same concentrations mentioned above; the stability period was fifteen weeks for $2.0 \mathrm{mg} / \mathrm{L}$ and six weeks for $0.2 \mathrm{mg} / \mathrm{L}$, when the samples were stored at $-20^{\circ} \mathrm{C}$. When stored at $4{ }^{\circ} \mathrm{C}$, samples containing $0.2,2.0$ and $5.0 \mathrm{mg} / \mathrm{L}$ remained stable during 10 days.

Statistical analysis: The non-parametric Friedman test ( $\mathrm{p}=0.025$ ) was used to assess significant differences between the ttMA values in samples collected in three different periods and Mann-Whitney test (U-test) $(\mathrm{p}=0.05)$ to verify differences according to personal habits of volunteers: tobacco, alcohol and sorbic acid in diet. For all statistical calculations the SAS software package was used.

\section{RESULTS}

Mean $( \pm$ SD) and median values of ttMA in the urine were respectively $0.40( \pm 0.55) \mathrm{mg} /$ gcreatinine and 0.17 $\mathrm{mg} /$ gcreatinine in pre-shift samples; $0.81( \pm 0.47) \mathrm{mg} /$ gcreatinine and $0.62 \mathrm{mg} /$ gcreatinine in post-shift samples. In the morning of the day after (12-16 $\mathrm{h}$ after exposure) the mean was $0.41( \pm 0.27) \mathrm{mg} / \mathrm{gcreatinine}$ and the median was $0.27 \mathrm{mg} / \mathrm{gcreatinine}$. In these periods the minimum and maximum values were $0.1-1.09 \mathrm{mg} / \mathrm{gcreatinine}$ (preshift); 0.1-1.87 mg/gcreatinine (post-shift) and 0.1-1.06 $\mathrm{mg} / \mathrm{gcreatinine}$ (the day after following day).

The ttMA values in the samples collected at the end of the shift were greater and significantly different $(p=$ 0.025 ) from those detected in pre-shift samples and those of the following day after (Figure 1).

Table II shows ttMA in urine according to smoking, drinking, and sorbic acid in diet in post-shift samples.

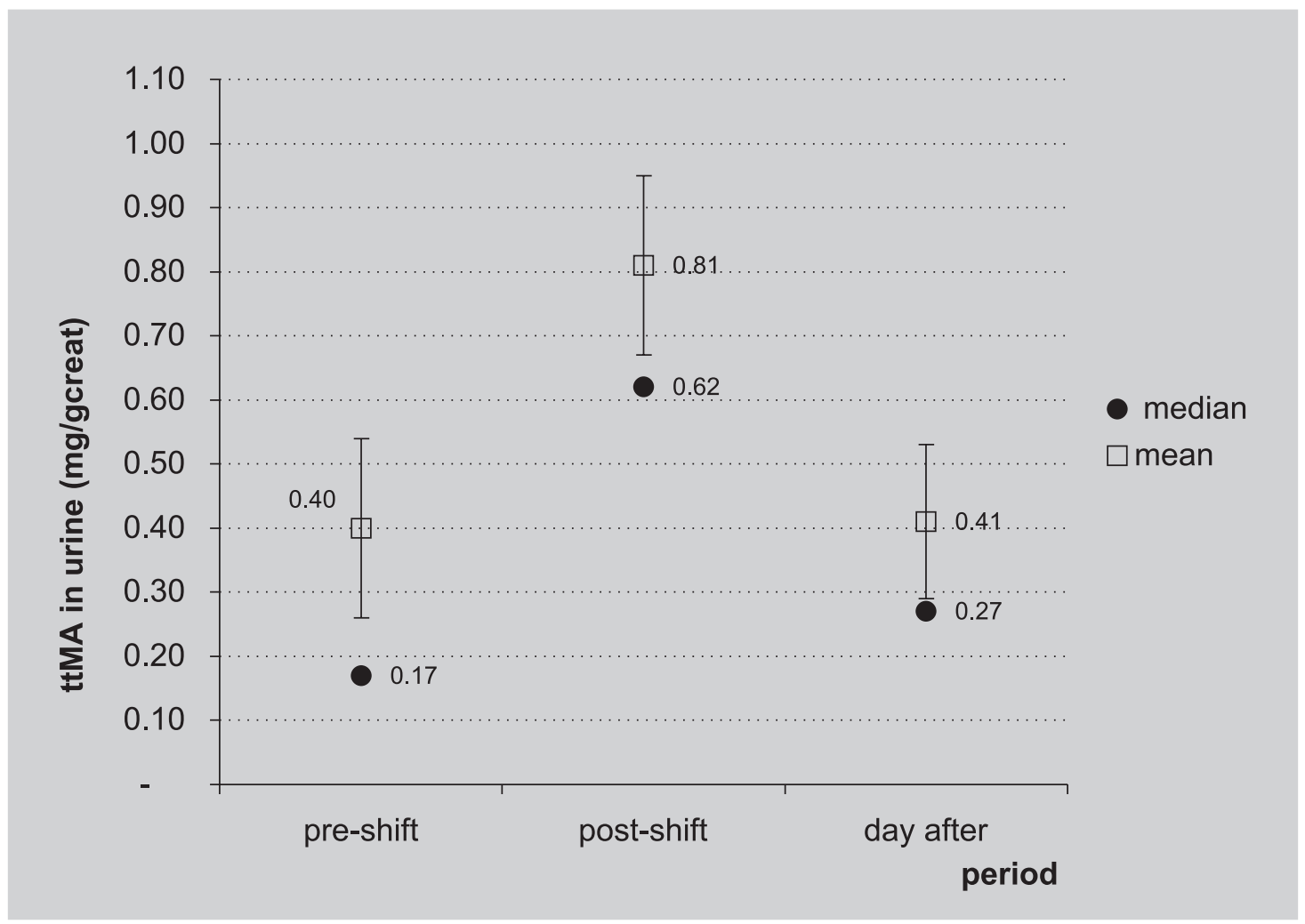

FIGURE 1- Representation for mean and median results of urinary trans, trans-muconic acid in mg/gcreatinine, in samples collected in pre-shift, post-shift and in the morning after from benzene handling workers. 
TABLE II - Trans, trans-muconic acid in urine (mg/g creatinine) from post-shift samples according to alcohol, tobacco and sorbic acid from diet in the exposed population $(n=25)$

\begin{tabular}{|c|c|c|c|c|c|c|}
\hline & \multicolumn{2}{|c|}{ Tobacco use } & \multicolumn{2}{|c|}{ Sorbic acid in diet } & \multicolumn{2}{|c|}{ Alcohol intake* } \\
\hline & Yes $(n=6)$ & No $(n=19)$ & Yes $(n=10)$ & No $(n=15)$ & Yes $(n=11)$ & No $(n=14)$ \\
\hline Mean & 0.82 & 0.80 & 0.84 & 0.78 & 0.51 & 1.1 \\
\hline Median & 0.63 & 0.61 & 0.66 & 0.58 & 0.42 & 0.81 \\
\hline SD & 0.51 & 0.78 & 0.75 & 0.64 & 0.41 & 0.62 \\
\hline
\end{tabular}

* significantly different according to Mann-Whitney test (U-test) $(p=0.05)$

\section{DISCUSSION}

Trans,trans-muconic acid chromatographic analysis was performed using the principles of ducos et al. (1990) method. The extraction using SPE (Dowex), was based on the technique proposed by Lee et al. (1993) process that eliminates matrix interferences resulting in better resolution and sensitivity. The method validated on laboratory conditions showed reliable analytical parameters that allow its application in biomonitoring workers exposed to benzene through urinary ttMA.

Due to the non-normal distribution of data (ShapiroWilks test), non-parametric statistical tests were used. Statistical differences between the levels of ttMA in the three periods of sample collection was observed in exposed individuals (Friedman test, $p=0.025$ ) (Figure 1). Values of ttMA in urine shows that the samples taken at the end of the shift have significantly higher values in comparison with those measured at pre-shift as well as those determined in the following day $(p=0.225)$. On the other hand, there was no difference between ttMA levels in samples collected after and in the day before handling benzene. This result shows that there is no accumulation of the metabolite after benzene exposure only once a week and that the end of the working shift is the period of greater analyte excretion and should be chosen for sample collection.

In samples collected before the shift, ttMA levels were between 0.10 to $1.09 \mathrm{mg} / \mathrm{g}$ creatinine (mean $=0.40$; median=0.17). Some of the workers were smokers (6) and others habitually ingested foods with sorbic acids (10), such as fruit juices and margarine, according to the questionnaires filled out by each volunteer. Perhaps these personnel habits may rise ttMA levels, once the mean and median values found in samples taken before the shift (reference values) were slightly higher than those reported by Scherer et al. (1998) (mean= $0.14 \mathrm{mg} / \mathrm{g}$ creatinine).

Urinary ttMA levels between 0.9 and $1.9 \mathrm{mg} / \mathrm{g}$ creatinine have been associated with exposure to $1 \mathrm{ppm}$ benzene (Inoue et al., 1989; Scherer et al., 1998). Taking into account the value of $1.6 \mathrm{mg} t \mathrm{tMA} / \mathrm{g}$ creatinine as the biological value corresponding to the exposure to $1 \mathrm{ppm}$ of benzene (Brasil, 2001), 8.0\% of the workers showed results exceeding this value (after exposure).

No significant differences on ttMA levels were detected between smokers and non-smokers as well as among people consuming food containing sorbic acid. According to the results related by Lee et al. (1993) and Ong and Lee (1994), smokers occupationally exposed to benzene excreted more ttMA in urine than the nonsmokers. The low levels of ttMA in the population studied as well as the few smokers in the group $(n=6)$ could explain the results, although Vivoli et al. (1995), found results similar to ours in a study conducted on urban population (exposed to low benzene levels). Influence of sorbic acid, related to quantity and frequency of foods containing this substance, on ttMA excretion was described by some authors (Ducos et al., 1992; Medeiros et al., 1993; Ong, Lee, 1994; Ghittori et al., 1996), However, the population submitted to this study did not show significant differences in post-shift urine ttMA levels.

The influence of alcohol on urinary ttMA values was observed: drinkers showed lower urinary ttMA than non-drinkers in post-shift samples (Mann-Whitney (Utest) $p=0.05$ ), probably due to the inhibition of some enzymes by alcohol ingestion. We classified as drinkers people consuming some kind of alcohol beverage at least 4 times a week (minimum $20 \mathrm{~g}$ alcohol a week). Such effect is well documented for low molecular weight solvents (Apostoli, Alessio, 1995).

In fact, these results are not sufficient to outline the real dimension of the factors interfering with urinary ttMA levels, and further studies with greater number of subjects and in different exposure conditions could clarify the magnitude of individual habits on ttMA excretion. 


\section{RESUMO}

\section{Ácido trans,trans-mucônico em amostras de urina, coletadas em três períodos, de trabalhadores que manipulam benzeno em uma refinaria brasileira}

O ácido trans,trans-mucônico (ttAM), um produto de biotransformação do benzeno, tem sido recomendado como um bioindicador sensivel na biomonitorização de trabalhadores expostos ao benzeno. O presente estudo objetivou avaliar o melhor periodo de coleta da amostra de urina, para a análise do ttAM. Este bioindicador foi determinado em trabalhadores que manipulavam benzeno e as amostras foram coletadas em três periodos: pré-jornada (níveis basais individuais), pós-jornada e no dia seguinte à exposição. $O$ analito (ttAM) foi analisado por cromatografia líquida de alta eficiência (CLAE), detector $U V$, com uma coluna de fase reversa LiChrosorb RP 18, após extração com resina Dowex $1{ }^{\circledR}$ (aniônica fortemente básica). Nos trabalhadores avaliados, os valores de ttAM foram significativamente maiores nas amostras coletadas no periodo pós-jornada $(p=0.025)$, em relação àqueles obtidos nas amostras coletadas no período e no dia seguinte. Para a biomonitorização da exposição através da análise do ttAM, os resultados obtidos indicaram o final da jornada como o período mais adequado para a coleta da urina. O hábito de fumar e a ingestão de alimentos contendo ácido sórbico não demonstraram influência nos níveis de ttAM na urina. Todavia, a ingestão de bebidas alcoólicas diminuiu significativamente a excreção deste bioindicador.

UNITERMS: Ácido trans,trans-mucônico. Benzeno. Biomonitorização

\section{REFERENCES}

AMERICAN CONFERENCE OF GOVERNMENTAL INDUSTRIAL HYGIENISTS. Threshold limit values for chemical substances and physical agents. Biological exposures indices. Cincinatti: ACGIH, 1998. 179 p.

AMERICAN CONFERENCE OF GOVERNMENTAL INDUSTRIAL HYGIENISTS. Threshold limit values for chemical substances and physical agents. Biological exposures indices. Cincinatti: ACGIH, 2002. 219 p.

APOSTOLI, P.; ALESSIO, L. Fatori condizionanti assorbimento e metabolismo del benzene. In: MINOIA C.; APOSTOLI P.; BARTOLUCCI G.B., eds. Il benzene: tossicologia, ambienti di vita e di lavoro. Milano: Morgan, 1995. p.17-26
BECHTOLD, W.E.; HENDERSON, R.F. Biomarkers of human exposure to benzene. J. Toxicol. Environ. Health, Washington, v.40, p.377-386, 1993.

BECHTOLD, W.E.; LUCIER, G.; BIRNBAUM, L.S.; YIN, S.N.; LI, G.L.; HENDERSON, R.F. Muconic acid determinations in urine as a biological exposure index for workers occupationally exposed to benzene. Am. Ind. Hyg. Assoc. J., Akron, v.52, p.473-478, 1991.

BRASIL. Ministério do Trabalho e Emprego. Portaria n ${ }^{0} 34$ de 20 de dezembro de 2001. Diário Oficial da União, Brasília, DF, 27 dez. 2001. p.260-261.

DUCOS, P.; GAUDIN, N.R.; ROBERT, A.; FRANCIN, J.M.; MAIRE, C. Improvement in HPLC analysis of urinary trans,trans-muconic acid, a promissing substitute for phenol in the assessment of benzene exposure. Int. Arch. Occup. Environ. Health, Berlin, v.62, p.529-534, 1990.

DUCOS, P.; GAUDIN, R.; BEL, J.; MAIRE, C.; FRANCIN, J.M.; ROBERT, A.; WILD, P. Trans, trans-muconic acid, a reliable biological indicator for the detection of individual benzene exposure down to the ppm level. Int. Arch. Occup. Environ. Health, Berlin, v. 64, p.309-313, 1992.

GHITTORI, S.; MAESTRI, L.; FIORENTINO, M.L.; IMBRIANI; M. Evaluation of occupational exposure to benzene by urinalysis. Int. Arch. Occup. Environ. Health, Berlin, v.67, p.195-200, 1995.

GHITTORI, S.; MAESTRI, L.; ROLANDI, L.; LODOLA, L.; FIORENTINO, M.L.; IMBRIANI M. The determination of trans,trans-muconic acid in urine as an indicator of occupational exposure to benzene. Appl. Occup. Environ. Hyg, Cincinatti, v.11, 187-191, 1996.

INOUE, O.; SEIJI, K.; NAKATSUKA, H.; WATANABE, T.; YIN, S-N.; LI, G-L.; CAI, S-X.; JIN, C.; IKEDA, M. Urinary $t, t$-muconic acid as an indicator of exposure to benzene. Br. J. Ind. Med.,London, v.46, p.122-127, 1989.

INTERNATIONAL AGENCY FOR RESEARCH ON CANCER. Monographs on the valuation of carcinogenic risk of chemicals to humans: Benzene. Lyon: IARC, 1982. no $29,93 \mathrm{p}$. 
KIRLEY, T.A.; GOLDSTEIN, B.D.; MANIARA, W.N.; WITZ G. Metabolism of trans,trans-muconaldehyde, a microssomal hematotoxic metabolite of benzene, by purified yeast aldehyde dehydrogenase and a mouse lever soluble fraction. Toxicol. Appl. Pharmacol., Canada, v.100, p.360-367, 1989.

LEE, B.L.; NEW, A.L.; KOK, P.W.; ONG, H.Y.; SHI, C.Y.; ONG, C.N. Urinary trans, trans-muconic acid determined by liquid chromatography: application in biological monitoring of benzene exposure. Clin. Chem., Wiston-Salem, v.39, p.1788-1792, 1993.

MEDEIROS, A.M.; BIRD, M.G.; WITZ G. Potential biomarkers of benzene exposure. Toxicol. Environ. Health, Washington, v.40, p.377-386, 1993.

ONG C.N.; LEE B.L. Determination of benzene and its metabolites: application in biological monitoring of environmental and occupational exposure to benzene. $J$. Chromatogr. B, v.660, Amsterdan, p.1-22, 1994.
ONG, C.N.; KOK, P.W.; ONG, H.Y.; SHI, C.Y.; LEE, B.L.; PHOON, W.H.; TAN, K.T. Biomarkers of exposure to low concentrations of benzene: a field assessment. Occup. Environ. Med., London, v.53, p.328-333, 1996.

SCHERER, G.; RENNER, T.; MEGER, N. Analysis and evaluation of trans-trans-muconic acid as a biomarker for benzene exposure. J. Chromatogr. B, Amsterdan, v. 717, p. 179-199, 1998.

VIVOLI, G.; ROVESTI, S.; BERGOMI, M.; VIVOLI, R.; FERRARI, A. Monitoraggio dell'exposizione a benzene in ambiente urbano. In: MINOIA C.; APOSTOLI P.; BARTOLUCCI G.B., eds. Il benzene: toxicologia, ambienti di vita e di lavoro. Milano: Morgan, 1995. p. 303-309.

Recebido para publicação em 18 de agosto de 2003. 